\title{
NADĚJE NA ZMRTVÝCHVSTÁNÍ? Zamyšlení u hrobu Bernarda Bolzana na Olšanských hřbitovech dne 29. zář́i 2010
}

\author{
Lubomír Sršeň (Praha)
}

Redakce Matičních listů se rozhodla po více než 10 letech otisknout text úvahy, kterou pronesl PhDr. Lubomir Sršeň, člen Matice české, při přiležitosti dokončené opravy hrobu Bernarda Bolzana v záŕi 2010. K tomuto rozhodnutí vedlo přesvědčení, že hlavni myšlenky proslovu jsou stále aktuální. S mírným optimismem vítáme naději, že se péče o hroby našich předků stává v poslednich letech předmětem zájmu osvícených správcủ hřbitovi̊ i mnohých dobrovolniku z řad občanì. Doufejme, že podobné úvahy a výzvy, jako je ta zde otištěná, povedou k postupné kultivaci vztahu naši společnosti $k$ minulosti.

\section{Vážení přátelé,}

při úvahách o tom, co vás sem dnes prrivedlo, jsem došel $\mathrm{k}$ přesvědčení, že to jistě není jen zvědavost na to, jak dopadla drobná oprava kamenného náhrobku kryjícího ostatky Bernarda Bolzana. Soudím, že vás přitahuje především samotná osobnost člověka, který je zde pohřben a k němuž máte patrně každý z vás nějaký bližší vztah. Dnešní připomínku letošního zdařilého restaurování poškozeného náhrobku chápu tedy především jako příležitost připomenout si člověka, jemuž jsme stále mnoho dlužni.

Přesto mi dovolte nejprve stručně shrnout fakta, jež se stala podnětem k dnešnímu setkání. Vy, kteří jste obeznámeni s životními osudy Bernarda Bolzana, víte, že uzavřel se svým př́telem a těchobuzským hostitelem Josefem Hoffmannem nezvyklou dohodu. Ten, kdo z nich zemře dř́ive, bude pohřben po boku Hoffmannovy ženy Anny, jež odešla na věčnost už v roce 1842 a byla pochována v Těchobuzi. Tomu, kdo zemře později, bude pak určeno nejbližší volné místo. Tato úmluva vyplynula ze zcela výjimečného vztahu Bernarda Bolzana k Anně Hoffmannové, jež byla po 19 let jeho oddanou mateřskou př́telkyní, mimořádně vzdělanou spolupracovnicí, obětavou pečovatelkou o jeho zdraví a několikrát se stala doslova zachránkyní jeho života. Přestože Bolzano zemřel o tři roky dříve než Josef Hoffmann, 18. prosince 1848 , nepřipustili jeho blízcí z obavy před pomluvami, aby byla dohoda dodržena. Jan Křtitel Bolzano dal pohřbít svého bratra do rodinného hrobu na Olšanské hřbitovy, pod jednoduchý železný kříž, doplněný skromnou mramorovou deskou s latinským nápisem. V roce 1858 byl napravo od svého učitele pohřben jeho věrný žák František Schneider, profesor náboženství na pražské polytechnice

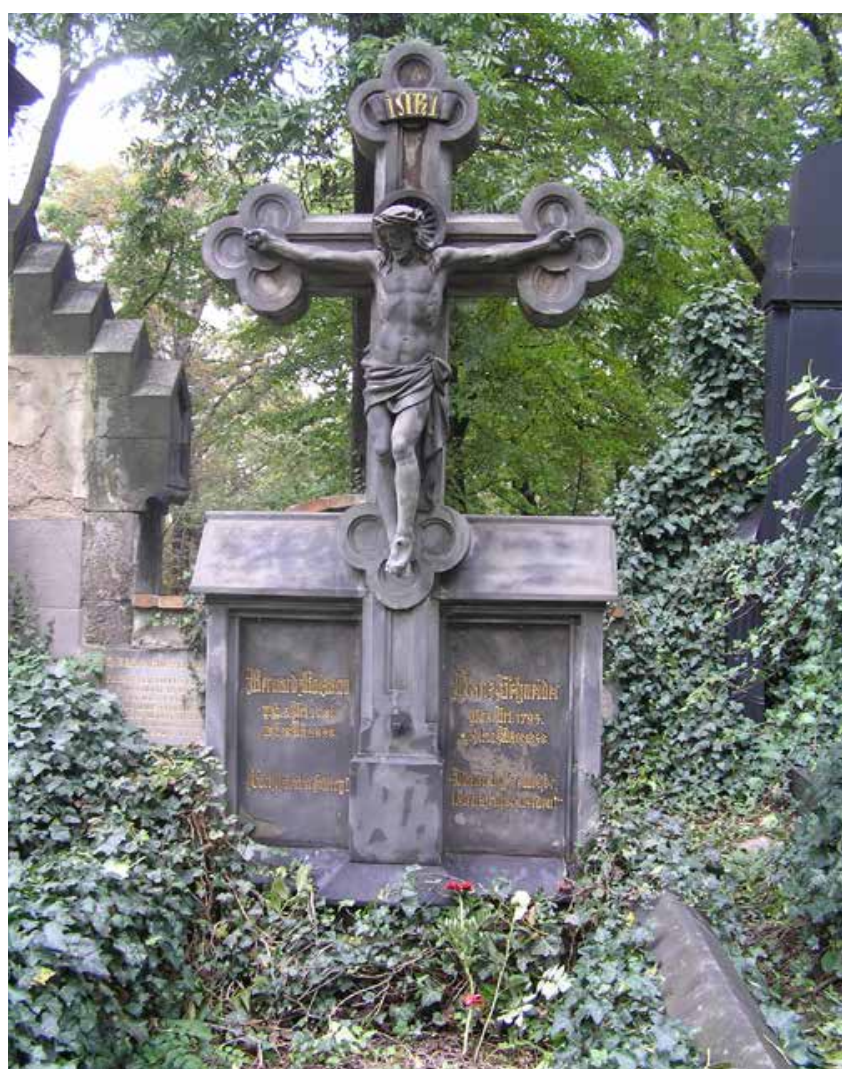

Obr. 1. Hrob Bernarda Bolzana a jeho blízkých na Olšanských hřbitovech (hřbitov III, odd. 9, čís. 107), stav v r. 2010. Foto L. Sršeň.

a ředitel stavovské reálky v Praze, mj. učitel dětí v rodině Františka Palackého. Po dvou letech, roku 1860, dal architekt František Šebek zbudovat pro oba své oblíbené učitele, Bernarda Bolzana a Františka Schneidra, v těsné blízkosti jejich hrobů společnou hrobku. Její kamenný náhrobek ve stylu neogotiky ozdobil pražský sochař Josef Effenberger pískovcovým krucifixem. Bolzanovy a Schneidrovy ostatky byly tehdy exhumovány a pietně přeneseny na nové místo. Původní mramorové desky z Bolzanova a Schneidrova hrobu zůstaly dodnes zasazeny na svém místě, ve zdi za stávající hrobkou. Do hrobky byli později pohřbeni ještě další dva muži, prof. Josef Šauer z Augenburgu (1917), ctitel Bolzanova učení, a Jan Schneider (1939), prasynovec Františka Schneidra, vrchní policejní ředitel. 
Před několika lety mi prrinesla do muzea moje bývalá spolužačka, dr. Helena Soukupová, několik pískovcových úlomků, které při náhodné procházce našla na Bolzanově hrobě. „Nějaký vandal urazil Kristovi chodidla. Ty ses Bolzanem zabýval a znáš se s kamenosochaři, tak se postarej, aby se to dalo do pořádku. "Poprosil jsem tedy akademického sochaře Jiř́iho Živného, nejsolidnějšího restaurátora kamene, kterého znám, jenž pro nás restauroval kdysi mnoho soch v Lapidáriu, aby tam prŕíležitostně ty fragmenty doplnil. Gratis, pochopitelně, jen kvůli mně a kvůli Bolzanovi. Ochotně to slíbil. Ale zápasil bud' s časem a urgentními zakázkami doma i v cizině, nebo s nevhodným počasím, a tak musel tento dobročinný akt stále odkládat.

Teprve nedávno se podařilo uvést vše do pohybu. Díky Matici české, Národnímu muzeu, štědrému soukromému sponzorovi a Svatoboru dostala akce oficiální ráz a pan Živný práci provedl zcela standardně a profesionálně, včetně restaurování celého krucifixu. Dnešního setkání se sice nemůže účastnit - restauruje zrovna kdesi ve Francii - ale snad si najde chvíli, odloží ostych, potlačí svou nezištnost a časem pošle i očekávanou řádnou fakturu, aby bylo vše řádně a úředně dovršeno.

Bolzano by nejspíše považoval naše úsilí udržet jeho náhrobek v dobrém stavu za malichernost a zbytečnost. Byl v těchto věcech překvapivě nesentimentální, racionální, až chladně pragmatický. I dnešního člověka zaráží, když čte v jeho závěti doporučení, aby jeho mrtvé tělo bylo využito $\mathrm{v}$ pitevně libovolným způsobem $\mathrm{k}$ vědeckým účelům. Je známo, že vnější projevy uznání a kultu k celebritám považoval za nicotné, pokud nevyplývaly z hlubšího ocenění jejich díla a myšlenkového odkazu. Ve vlastním životopise souhlasil s řeckým Themistoklem, ,který raději chtěl, aby se jednou ptali, proč mu nebyla postavena žádná socha, než proč mu byla postavena socha“.

Procházíme-li dnes Olšanskými hřbitovy, neubráníme se pocitu zmaru a zkázy. Ten není vyvoláván pouze oním přirozeným faktem, že tu nad živými převládají svým počtem mrtví. Mnohem drtivěji působí zjevná neúcta $\mathrm{k}$ mrtvým předkům, cynicky demonstrovaná všudypř́itomným vandalismem, který už poničil značné množství zdejších náhrobků. Je proto třeba, abychom nebyli naivní a přiznali si, že drobná oprava jednoho z náhrobků je jen málo účinným, téměr̆ bezvýznamným projevem marného vzdoru proti sklonu současné české společnosti ke ksindlizaci - jak to nazýval surově, ale trefně prof. Alexandr Stich.

V souladu s Bolzanovými názory však není nutno propadat beznaději. Vždyt' opravdu není důležité, zda se do budoucích věků dochová Bolzanův náhrobek, nebude ani žádnou tragédií, když naši potomci zapomenou, kde byl Bolzano pochován, dokonce bude „naprosto lhostejné“, jak uvedl sám Bolzano, „,bude-li potomstvo znát slabiky, z nichž se skládá jeho jméno ". Z tohoto úhlu pohledu bude jistě i Národnímu muzeu odpuštěno, že dodnes do svého Panteonu neumístilo Bolzanovu bystu, odlitou v bronzu pro tuto síň slávy už na přelomu 19. a 20. století.* Toto vše není podstatné.

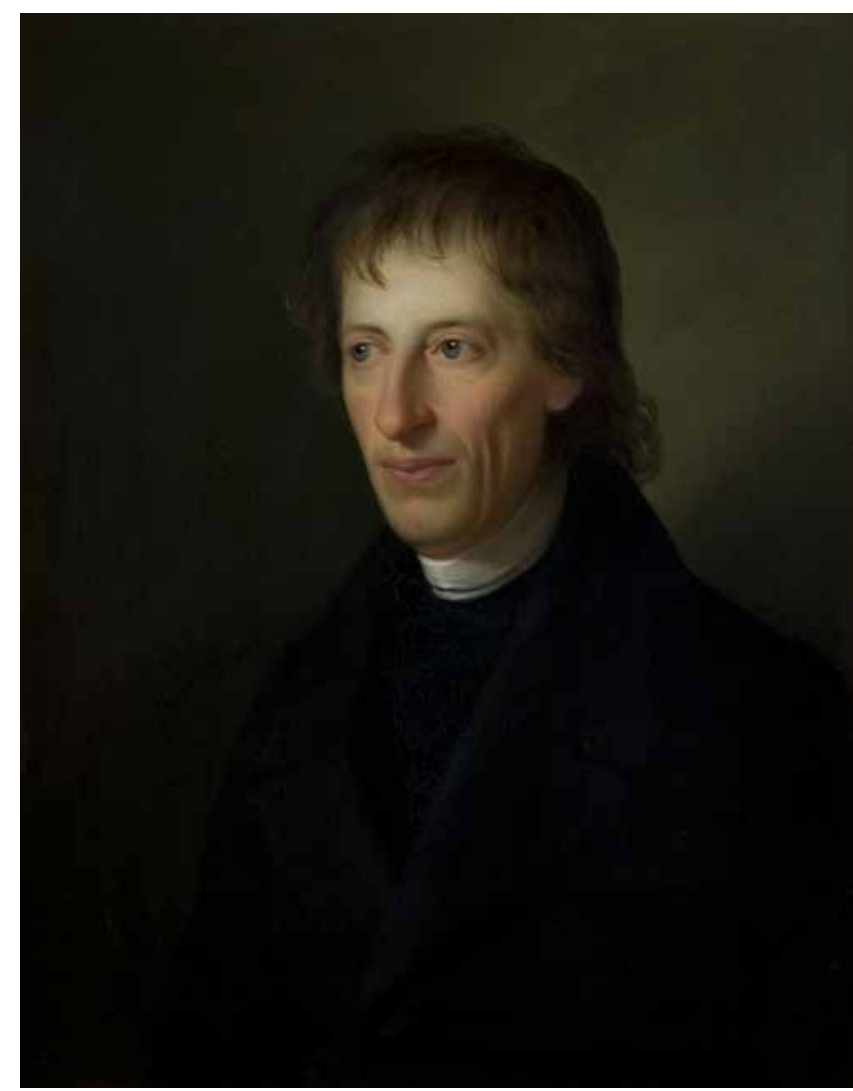

Obr. 2. Bernard Bolzano na portrétu od Heinricha Hollpeina z let 1839-1840. Olej na plátně, Národní muzeum, inv. čís. H2-5665. Foto Radovan Boček.

Důležité však je, abychom přestali považovat Bolzana za cizince, a konečně uznali, že je to pražský rodák a Čech. Má nám snad vadit, že se jeho otec narodil v Itálii (ale od dětství žil v Praze), že jeho matka, rodilá Pražanka, hovořila německy? Máme i dnes vyčítat Bolzanovi, že se jeho mateřským jazykem stala němčina? Vždyt' šlo o jeden ze dvou jazyků, kterým tehdy mluvili obyvatelé této země! Je třeba připomínat Bolzanova básnická díla a kázání opěvující jeho českou vlast? Je nutné stále opakovat, že Bolzano za celý svůj život nikdy nevycestoval za hranice Čech? Jakou ironií osudu je tedy fakt, že Bolzana jako vynikajícího filozofa, estetika, matematika a zakladatele moderní logiky dnes vydávají a studují v Izraeli, Rusku, Japonsku, Spojených státech a v dalších vyspělých zemích - a my se stále ostýcháme se k němu hlásit!

V roce 1972 se pustilo nakladatelství Frommann Holzboog ve Stuttgartu do vydávání veškerých dokladů o Bolzanově životě a díle pod názvem Bernard BolzanoGesamtausgabe. Výsledkem grandiózního vydavatelského počinu, na němž spolupracují i někteří čeští vědci, bude asi přes 100 objemných svazků. Pokud vím, tak kompletní řadu již vydaných knih této edice mělo v naší republice jen Bolzanovo studijní centrum zřízené po sametové revoluci slavnostně v Bolzanově úmrtním domě v Celetné ulici. To však po čase nenápadně zaniklo. Ani v našich předních státních knihovnách nejsou tyto svazky k dispozici.

\footnotetext{
* Po osmi letech od tohoto proslovu byla zmíněná křivda napravena. Bolzanova bysta byla do Panteonu Národního muzea umístěna v rámci reorganizace jeho sochařské výzdoby roku 2018.
} 
Bolzanovo sociální, filozofické a teologické učení, nazývané bolzanismem, bylo doplňující i opoziční paralelou k hnutí českého obrození a sehrálo významnou roli při kultivaci společnosti v Čechách 19. století. Nekrolog na Bolzana v Havlíčkových Národních novinách z 22. prosince 1848 to dobře vystihl známými slovy: „Pomnikem jeho nejkrásnějším a nejtrvalejším jest, že svobodné pohybování ducha $v$ naši vlasti jest namnoze plod semene, které on rozsíval. "

Po nejistém a opatrném přešlapování kolem Bolzanova odkazu, charakteristickém pro českou společnost ve 20. století, se nyní, v 21. století, v době demokracie, svobody a odbouraných mýtů a předsudků, můžeme $\mathrm{k}$ Bolzanovi bez zábran a obav přihlásit. $\mathrm{O}$ jeho objevech v matematice a logice, kterými předstihl svou dobu, víme pouze to, že fascinují a inspirují specialisty na celém světě. Většina z nás, laiků, je však není schopna plně ocenit, nebot' jim nerozumíme.

Přesto je Bolzano v mnoha dalších oblastech svého učení i v osudech svého života srozumitelný a stále velmi aktuální. Je to především jeho touha po svobodě a samostatném myšlení, jež dohnala tehdejší represivní režim císaře Františka I. až k jeho odvolání z působení na pražské univerzitě. Stále inspirativní je i jeho životní zásada, že každý by měl usilovat o vlastní štěstí a současně o štěstí svých bližních. Velmi moderní jsou dodnes jeho exhorty (nedělní kázání pro univerzitní studenty i pražské měšt'any), v nichž zcela svobodně a otevřeně hlásal své myšlenky. Najdeme tu např. jeho přesvědčení o významné úloze jedince při nápravě společnosti, o lásce k vlasti, o významu občanské společnosti, o rovnoprávnosti žen, o nebezpečí plynoucím z nevzdělanosti lidí, o vztahu českých a německých obyvatel Čech, o poměru křest'anů k Židům, ale také o důležitosti žertování a veselé mysli.

Aby každá myšlenka či úvaha nesla také - ve shodě s Bolzanovými názory - skutečné ovoce, dovoluji si vám doporučit: pokud jste tak už neučinili, přečtěte si inspirativní Bolzanovy Exhorty, vydané Nakladatelstvím Lidové noviny v roce 2006, strhující Bolzanův Vlastní životopis, připravený Marií Pavlíkovou a vydaný Odeonem v roce 1981, či monografii o Bolzanovi, již napsal Jaromír Loužil a jež vyšla v melantrišských Odkazech pokrokových osobností naší minulosti roku 1978. Věřím, že vás Bolzano nadchne a že se přidáte $\mathrm{k}$ těm, kteří ho považují za jednoho z největších rodáků naší vlasti.

\author{
Lubomír Sršeň \\ Národní muzeum - Historické muzeum \\ oddělení starších českých dějin \\ Vinohradská 1 \\ 11000 Praha 1
}

